\title{
Kearifan Lokal Musikal dalam Lagu-lagu Album Bali Kumara
}

\author{
I Putu Lukita Wiweka Nugraha Putra \\ Program Studi Musik, Institut Seni Indonesia Denpasar \\ email: lukitawiweka@isi-dps.ac.id
}

\begin{abstract}
ABSTRAK
Topik dari artikel ini adalah kearifan lokal pada lagu-lagu album Bali Kumara I. Tujuan dari penulisan artikel ini adalah untuk mendeskripsikan kearifan lokal pada lagu-lagu album Bali Kumara. Metode yang digunakan dalam studi ini adalah deskriptif kualitatif. I Komang Darmayuda selaku komposer lagu-lagu album Bali Kumara merupakan informan dalam penelitian ini. Data berupa rekaman audio lagu-lagu album Bali Kumara. Kearifan lokal dalam lagu-lagu album Bali Kumara terletak pada penggunaan tangga nada/titi laras pelog dan slendro, serta penggunaan bahasa Bali singgih dan sor. Tangga nada pelog dan slendro diimplementasikan pada melodimelodi utama, baik oleh alat musik keyboard, gamelan, maupun vokal. Pada beberapa lagu terdapat juga tangga nada lain, seperti diatonis dan kromatis, dimana tidak terlalu memudarkan warna pelog dan slendro. Jika dilihat dari sudut pandang sor singgih basa (tingkatan-tingkatan dalam bahasa Bali), sebagain besar lagu-lagu di album Bali Kumara menggunakan basa singgih, dan beberapa di antaranya menggunakan basa sor. Lagu pop Bali sebagai salah satu kesenian profan yang tumbuh dan berkembang di Bali sudah seyogyanya mengandung unsur-unsur kearifan lokal Bali. Kearifan lokal yang terkandung pada lagu-lagu album Bali Kumara dapat menjadi pijakan bagi para pelaku lagu pop Bali khususnya komposer dalam menciptakan karya-karya berikutnya, sehingga identitas lagu Pop Bali tetap terjaga.
\end{abstract}

Kata kunci: musik, kearifan lokal, lagu, album Bali Kumara.

\begin{abstract}
The topic of this article covers local wisdom in the songs of Bali Kumara first album. The purpose of writing this article is to describe the local wisdom in the songs of the Bali Kumara first album. The method used in this study is descriptive-qualitative. I Komang Darmayuda as a composer of Bali Kumara first Album songs is an informant in this research. The data is audio recording of songs in Bali Kumara first album. The Balinese local wisdom in the songs of Bali Kumara first album lies in the use of tone named titi laras pelog and slendro, as well as the use of the Balinese language such as singgih and sor. Pelog and slendro tones are implemented in the
\end{abstract}


main melodies, either by keyboard instruments, gamelan or vocals. In some songs, there are also other scales, such as diatonic and chromatic, which do not diminish the pelog and slendro colors. Seen from the point of view basa singgih (levels in the Balinese language), most of the songs in the album Bali Kumara uses basa singgih, and some basa sor. Balinese pop songs as one of the profane art that grow and develop in Bali should contain elements of the Baliense local wisdom. The local wisdom contained in the songs of Bali Kumara album can be a foothold for the performers of Balinese pop songs especially composers in creating works, so that the identity of the Balinese pop songs is maintained.

Keywords: music, local genius, song, album of Bali Kumara.

\section{PENDAHULUAN}

Kearifan berasal dari kata "arif" yang berarti cerdik pandai; berilmu (Kamus Besar Bahasa Indonesia, 1990: 48) sedangkan "lokal” menurut Kamus Besar Bahasa Indonesia (1990: 530) dapat diartikan sebagai setempat; terjadi (berlaku, ada, dsb) di satu tempat saja, tidak merata. Prabandani (2018) dalam artikelnya "Pembangunan Hukum Berbasis Kearifan Lokal" menjelaskan,

"pengertian kearifan lokal adalah nilai-nilai, norma, hukum-hukum dan pengetahuan yang dibentuk oleh ajaran agama, kepercayaan-kepercayaan, tata nilai tradisional, dan pengalaman-pengalaman yang diwariskan oleh leluhur yang akhirnya membentuk sistem pengetahuan lokal yang digunakan untuk memecahkan permasalahan sehari- hari oleh masyarakat. Sedangkan unsur-unsur kearifan lokal adalah nilai, norma, hukum dan pegetahuan, sistem pengetahuan lokal, dan pemecahan permasalahan sehari-hari."

Berdasarkan pemaparan tersebut, kearifan lokal dapat diartikan secara sempit sebagai pengetahuan lokal yang berlaku di suatu daerah. Bahasa dan musik yang berlaku di suatu tempat merupakan salah satu pengetahuan lokal yang merupakan bagian dari kearifan lokal. Sartini dalam tulisan yang berjudul "Menggali Nilai-nilai Kearifan Lokal Budaya Jawa lewat Ungkapan” mengatakan bahwa salah satu kearifan lokal yang ada di seluruh nusantara adalah bahasa.

Pulau Bali dikenal karena keunikan dan kekayaan seni dan budayanya, baik di kancah nasional maupun internasional. Kesenian sebagai bagian dari kebudayaan telah menyatu dengan kehidupan masyarakat Bali. Kesenian tersebut bersifat sakral dan profan jika ditinjau dari segi fungsinya. Secara umum kesenian sakral dan profan yang tumbuh dan berkembang di Bali memiliki muatan kearifan lokal. 
Adapun kesenian-kesenian profan yang tumbuh dan berkembang di Bali, salah satunya adalah lagu pop Bali. Darmayuda (2007; xi) mengatakan bahwa lagu pop Bali adalah salah satu bentuk kesenian modern yakni terdiri dari unsur seni suara dan sastra yang dalam penyajiannya diiringi dengan musik modern seperti; drum, gitar, bass, gitar melodi, dan organ/keyboard. Untuk memperkuat warna lokalnya, lagu pop Bali sering dikombinasikan dengan unsur karawitan bali, seperti gender, suling, dan gamelan angklung (Setia, 1986:126; Dharna, 2002). Penggunaan bahasa Bali menjadi ciri khas yang sangat kental dalam lagu pop Bali. Selain menggunakan bahasa Bali sebagai ciri utamanya, melodi lagu pop Bali menggunakan nada pentatonis (tangga nada yang terdiri atas lima nada dalam satu oktaf) yaitu tangga nada pelog dan slendro, bahkan terkadang menggunakan nada sisipan (pemero) untuk memperindah melodinya (Darmayuda, 2007: 3). Identitas lagu pop Bali sendiri dapat diperkuat oleh penggunaan bahasa Bali dan titi laras pelog dan slendro. Dengan demikian, kearifan lokal Bali sebagai identitas lagu Pop Bali tercermin melalui penggunaan titi laras pelog dan slendro, serta bahasa Bali.

Lagu Pop Bali pertama kali masuk dalam industri rekaman sekitar tahun 1970-an yang dipelopori oleh Band Putra Dewata pimpinan Anak Agung Made Cakra dengan beberapa albumnya yakni "kusir dokar", "Putri Bulan", dan "Galang Bulan" (Darmayuda, 2007: 61). Warna lokal Bali sangat tercerminkan dalam albumalbum tersebut, seperti penggunaan titi laras pelog dan selendro dalam melodi, memasukkan instrumen musik Bali, serta menggunakan bahasa Bali dalam liriknya. Makna-makna yang terkadung dalam lirik lagu-lagunya mengungkap tentang keindahan alam, kehidupan masyarakat Bali, situasi dan kondisi masyarakat Bali saat lagu-lagu tersebut diciptakan. Dari sekian banyak lagu ciptaannya, Anak agung Made Made Cakra telah mampu mempertahankan identitas atau ciri khas lagu pop Bali, tanpa terpengaruh warna pop dari daerah lainnya, maupun warna pop lagu Indonesia atau pop Barat (Darmayuda, 2005: 4).

Seiring dengan perkembangan teknologi dan informasi di era globalisasi, lagu pop Bali nampak mengalami perubahan-perubahan dalam perkembangannya. Perubahan tersebut dapat dilihat dari sisi warna musik, bahasa, dan makna liriknya. Warna musik lagu pop Bali yang sedang trend di pasaran cenderung lepas dari warna lokal Bali, seperti tidak adanya unsur instrumen musik Bali dan penggunaan titi laras pelog dan slendro. Hal ini dapat dijumpai pada sejumlah group band yang membawakan lagu berbahasa Bali dengan genre rock, reggae, dan rock $n$ roll. 
Penggunaan bahasa Bali dalam liriknya sering dibarengi dengan penggunaan bahasa Indonesia, sehingga lagu pop Bali menggunakan campuran antara bahasa Bali dan bahasa Indonesia. Hal ini dapat dijumpai pada lagu-lagu group band Leyoonk Sinatra dan Kiss Band. Penggunaan bahasa Bali kasar seperti "bangsat" dan "cicing" juga kerap dijumpai, misalnya dalam lagu karya Lolot Band yang berjudulkan "Bangsat". Hal ini menunjukkan bahwa globalisasi telah mengakibatkan perubahan terhadap lagu pop Bali jika ditinjau dari segi warna musik, penggunaan bahasa. Secara tidak langsung kearifan lokal Bali yang pada mulanya tercermin dalam unsur musikal dan liriknya semakin kabur dengan adanya perkembangan perkembangan yang demikian.

Atas fenomena tersebut, kekawatiran pun muncul baik dari pihak akademisi dan pencipta lagu pop Bali. Dalam wawancara tidak terstruktur pada tanggal 3 Oktober 2015, Darmayuda selaku akademisi sekaligus pencipta lagu-lagu pop Bali mengatakan, "Lagu pop Bali jangan sampai kebablasan. Kebablasan dalam artian penggunaan bahasa Bali dan bahasa Indonesia yang dicampurkan serta hilangnya warna Bali dalam lagu pop Bali itu sendiri”. Dalam wawancara pada tanggal 3 Oktober 2015, Komang Raka selaku pencipta lagu pop Bali juga memaparkan bahwa perkembangan lagu pop Bali saat ini sangat pesat jika ditinjau dari munculnya lagu berbahasa Bali dengan genre-genre yang beragam. Namun jika dikaitkan dengan pengertian bahwa lagu pop Bali adalah lagu yang berwarna Bali dan menggunakan bahasa Bali, maka perkembangannya bisa dibilang menurun.

Di tengah-tengah kekawatiran tersebut, muncul sebuah album yang berisikan lagu-lagu pop Bali yang kental akan warna musik Bali, penggunaan bahasa Bali alus, dan makna lirik yang berisikan sifat optimisme, religi, dan nasehat. Album tersebut berjudul Bali Kumara. Lagu-lagu yang terdapat pada album Bali Kumara merupakan cerminan karya-karya lagu pop Bali era Anak Agung Made Cakra yang kembali dihadirkan di era perkembangan lagu pop Bali masa kini. Adapun judul-judul lagu dalam album Bali Kumara, yakni Bali Asri, Bali Jagat Seni, Bali Kasub, Bali Kumara, Bencana ring Bali, Dewi Saraswati, Lutung Jail, Medokaran, Muda Lara, Ngastitiang Jagat Bali, Pewaris Jagat Bali, Tangis Pertiwi, dan Taru Kelapane Suci. Album Bali Kumara sangat menarik untuk dikaji dari segi penggunaan titi laras pelog dan slendro, serta penggunaan bahasa Bali dalam lirik lagunya yang mencerminan kearifan lokal Bali. Hal ini bertujuan untuk memberi pandangan mengenai jatidiri lagu pop Bali sesuai dengan awal kemunculannya kepada pencipta dan pelaku lagu-lagu 
pop Bali, serta masyarakat di tengah-tengah fenomena lagu Pop Bali yang sedang berlangsung.

\section{METODE PENELITIAN}

Materi dalam penelitian ini adalah kearifan lokal Bali dalam lagu-lagu album Bali Kumara. Pendekatan yang digunakan dalam penelitian ini adalah pendekatan kualitatif. Fenomena kearifan lokal Bali dalam lagu-lagu album Bali Kumara akan dikaji dari sudut penggunaan titi laras atau tangga nada pelog dan slendro pada melodinya, serta penggunaan bahasa Bali pada liriknya.

Data primer dalam penelitian ini adalah data yang telah terdokumentasi dalam bentuk rekaman audio dan teks lirik lagu-lagu album Bali Kumara. Di samping itu, dilakukan juga wawancara secara langsung terhadap komposer, yaitu Komang Darmayuda dan Ni Luh Siartini di Banjar Tameng, Sukawati, Kabupaten Gianyar, Bali. Komang Darmayuda dan Ni Luh Siartini merupakan pendidik, pembina, dan seniman yang hingga kini masih aktif berkecimpung di dunia seni musik. Pertanyaan yang disampaikan difokuskan pada penggunaan kearifan lokal Bali dalam lagu-lagu album Bali Kumara. Studi dokumentasi dilakukan dengan cara mencari rekaman audio dan teks lirik lagu-lagu album Bali Kumara.

Teknik analisis data yang digunakan adalah analisis deskriptif kualitatif, yaitu menganalisis data yang telah diperoleh melalui analisis deskriptif kualitatif. Terakhir adalah penarikan kesimpulan yang disertai saran yang diperlukan.

\section{PEMBAHASAN}

Sebagian besar lagu-lagu yang terdapat dalam album Bali Kumara merupakan ciptaan dari seorang komposer dari desa Sukawati, Gianyar, Bali, yaitu I Komang Darmayuda. Darmayuda telah berkiprah dalam blantika musik Bali sejak tahun 1995 hingga sekarang, khususnya di bidang cipta lagu pop Bali. Adapun beberapa lagu lain juga diciptakan oleh Ni Luh Siartini. Komposer merupakan penentu dari sisi musikal dan makna yang terkandung sebuah lagu. Berdasarkan hal tersebut, wawancara terkait permasalahan yang diajukan dalam artikel ini dilakukan terhadap komposer selain melakukan analisis terhadap objek studi. 


\section{Kearifan Lokal dalam Lagu-Lagu Album Bali Kumara dari Aspek Musikal}

Kearifan lokal Bali dapat dilihat segi musikal, karena setiap daerah (lokal) memiliki pengetahuan musiknya tersendiri. Masyarakat Bali yang bersifat dinamis memunculkan berbagai jenis musik, salah satunya adalah karawitan. Secara garis besar, dalam karawitan Bali, digunakan dua titi laras atau tangga nada yakni pelog dan selendro. Dalam pertunjukan gong kebyar atau untuk mengiringi suatu tarian biasanya dalam sistem solfegio Bali adalah sebagai berikut: dang - ding - dong deng - dung - dang $=1$ (do) $-3(\mathrm{mi})-4$ (fa) -5 (sol) -7 (si) -1 (do). Menurut Sukerta (1998: 167), slendro adalah salah satu jenis laras yang digunakan pada perangkat gamelan Gender Wayang, Angklung, Joged Bumbung, dan Genggong. Jika disandingkan dengan sistem solfegio musik Barat, tangga nada atau titi laras slendro berbunyi: 1(do) - 2 (re)- 3 (mi)- 5 (sol)- 6 (la)- 1 (do). Dengan demikian, tangga nada atau titi laras pelog dan slendro merupakan bagian dari kearifan lokal Bali yang bersifat pengetahuan musikal. Kearifan lokal Bali dalam lagu-lagu album Bali Kumara dapat ditinjau dari sejauh mana penggunaan tangga nada atau titi laras pelog dan slendro pada melodinya. Berikut adalah pengamatan terhadap penggunaan tangga nada pelog dan slendro dalam lagu-lagu album Bali Kumara (tabel 1).

Tabel 1

Penggunaan Tangga Nada Pelog dan Slendro dalam Lagu-lagu Album Bali Kumara

\begin{tabular}{|l|l|c|c|c|c|c|}
\hline \multirow{2}{*}{ No. } & \multirow{2}{*}{ Judul Lagu } & \multicolumn{2}{|c|}{ Pelog } & \multicolumn{2}{c|}{ Slendro } & \multirow{2}{*}{ Tangga Nada Selain } \\
\cline { 3 - 6 } & & Instrumen & Vokal & Instrumen & Vokal & Pelog \& Slendro \\
\hline 1. & $\begin{array}{l}\text { Bali Asri } \\
\text { Lestari }\end{array}$ & + & + & - & + & - \\
\hline 2. & Bali Kasub & + & + & - & + & $\begin{array}{l}\text { Penggunaan tangga } \\
\text { nada diatonis oleh alat } \\
\text { musik keyboard. }\end{array}$ \\
\hline 3. & Bali Kumara & + & + & + & + & $\begin{array}{l}\text { Penggunaan tangga } \\
\text { nada diatonis oleh vokal } \\
\text { di akhir lagu }\end{array}$ \\
\hline 4. & $\begin{array}{l}\text { Bali Jagat } \\
\text { Seni }\end{array}$ & + & + & + & + & $\begin{array}{l}\text { Penggunaan tangga } \\
\text { nada diatonis oleh vokal } \\
\text { pada bagian refrain. }\end{array}$ \\
\hline
\end{tabular}


E-ISSN 2622-8211

\begin{tabular}{|c|c|c|c|c|c|c|}
\hline 5. & $\begin{array}{l}\text { Bencana ring } \\
\text { Bali }\end{array}$ & + & + & - & + & $\begin{array}{l}\text { Penggunaan tangga } \\
\text { nada diatonis oleh vokal } \\
\text { pada bagian interlude } \\
\text { dan outro. }\end{array}$ \\
\hline 6. & $\begin{array}{l}\text { Dewi } \\
\text { Saraswati }\end{array}$ & + & + & - & + & - \\
\hline 7. & I Lutung Jail & - & - & + & + & - \\
\hline 8. & Medokaran & + & + & - & + & \\
\hline 9. & Muda Lara & + & - & + & + & $\begin{array}{l}\text { Diatonis pada saat intro, } \\
\text { interlude, dan outro, } \\
\text { yang dimainkan oleh } \\
\text { instrumen keyboard }\end{array}$ \\
\hline 10. & $\begin{array}{l}\text { Ngrastitiang } \\
\text { Jagat Bali }\end{array}$ & + & + & + & + & \\
\hline 11. & $\begin{array}{l}\text { Peawaris } \\
\text { Jagat Bali }\end{array}$ & + & + & - & - & $\begin{array}{l}\text { Diatonis pada bagian } \\
\text { intro yang dimainkan } \\
\text { oleh instrumen } \\
\text { keyboard. } \\
\text { Diatonis yang } \\
\text { dinyanyikan oleh vokal. }\end{array}$ \\
\hline
\end{tabular}




\begin{tabular}{|l|l|l|l|l|l|l|}
\hline 12. & $\begin{array}{l}\text { Tangis } \\
\text { Pertiwi }\end{array}$ & - & - & + & + & - \\
\hline 13. & $\begin{array}{l}\text { Taru } \\
\text { Kelapane } \\
\text { Suci }\end{array}$ & - & - & + & + & $\begin{array}{l}\text { Tangga nada kromatis } \\
\text { yang dimainkan oleh } \\
\text { instrumen keyboard } \\
\text { pada bagian intro } \\
\text { Diatosnis yang } \\
\text { dinyanyikan oleh vokal }\end{array}$ \\
\hline
\end{tabular}

Keterangan:

$$
+=\text { ada }
$$

- = tidak ada.

Berdasarkan tabel 1, dapat disimpulkan bahwa penggunaan tangga nada pelog dan slendro pada melodi lagu-lagu album Bali Kumara sangat dominan. Adapun penggunaan tangga nada selain pelog dan slendro, yaitu tangga nada diatonis. Namun jika diperhatikan secara seksama, dominasi penggunaan tangga nada pelog dan slendro mampu memperkuat kesan Bali dari segi musikal. Hal ini menandakan bahwa secara musikal kearifan lokal Bali dari aspek musikal telah tercermin pada lagu-lagu album Bali Kumara.

Menurut pemaparan Darmayuda, dominasi terhadap penggunaan tangga nada pelog dan slendro merupakan salah satu kiatnya dalam memperkuat warna Bali dalam lagu-lagu album Bali Kumara. Memperkuat warna Bali dengan dominasi penggunaan tangga nada pelog dan slendro sekaligus merupakan bagian dari tujuan komposer untuk mengembalikan jatidiri lagu pop Bali di tengah-tengah perkembangannya yang tidak menentu.

\section{Kearifan Lokal dalam Lagu-lagu Album Bali Kumara dari Aspek Penggunaan Bahasa Bali}

Dalam penciptaan sebuah lagu, kata-kata merupakan medium yang sangat ampuh untuk menyampaikan pesan yang ingin disampaikan oleh pencipta. Demikian pula dalam penciptaan lagu pop Bali dimana penggunakan bahasa Bali menjadi suatu syarat mutlak untuk mempertegas identitasnya. Kata-kata yang dipilih untuk 
dituangkan ke dalam lagu dapat mencerminkan kreativitas dan keluasan wawasan seorang pengarang dalam memahami kata-kata yang ada (Darmayuda, 2007: 92).

Bahasa Bali merupakan salah satu kearifan lokal Bali. Dalam bahasa Bali terdapat tingkatan-tingkatan yang disebut Sor Singgih Basa. Menurut Adnyana (2014: 16), sor singgih basa Bali dapat dilakukan dengan dengan memilih kata-kata yang telah ada, yang tiap kata-kata tersebut memiliki nilai rasa sosial. Sor singgih basa dapat dibagi menjadi dua, yakni basa singgih dan basa sor (Tinggen, 1986: 3). Basa singgih adalah bahasa yang digunakan untuk menghormati orang yang patut dihormati, sedangkan basa sor adalah bahasa yang digunakan untuk berbiacara dengan orang sebaya dan untuk merendahkan orang yang patut direndahkan. Menurut Tinggen (1986: 3-6), basa singgih dapat dibagi menjadi basa alus singgih, alus mider, madia, dan basa alus mider, sedangkan basa sor dapat dibagi menjadi basa kesamen/kepara dan basa kasar.

Berdasarkan pengamatan yang dilakukan terhadap bahasa yang digunakan pada lirik lagu-lagu album Bali Kumara, ditemukan bahwa sebagaian besar lirikliriknya menggunakan basa singgih dan beberapa diantaranya menggunakan basa kesamen/kepara. Penggunaan basa singgih dapat dilihat pada lirik lagu "Bali Asri Lestari", "Bali Kasub", "Bali Jagat Seni”, "Bali Kumara", "Dewi Saraswati", "Medokaran", "Ngrastitiang Jagat Bali", "Pewaris Jagat Bali", "Tangis Pertiwi", "Taru Kelapane Suci". Penggunaan basa sor dapat dilihat pada lirik lagu "Bencana ring Bali”, yakni kata corah (jahat), nyag (hancur), jatma (manusia). Penggunaan basa sor tersebut lebih ditujukan kepada pelaku bom Bali dan sekaligus untuk merendahkan pelakunya. Basa sor juga terdapat pada lagu "I Lutung Jail", antara lain kata nguluk-nguluk (berbohong), I Lutung (si kera), luwung (bagus), dan lainlain. Basa sor pada lirik lagu "I Lutung Jail" merupakan bahasa pergaulan sesama anak sebaya, dimana penyanyi bercerita kepada temannya tentang kisah / Lutung (kera). Basa sor lirik lagu "Muda Lara", antara lain basange sing misi ape (belum makan seharian), dekil (kotor), manjus (mandi). Kata-kata tersebut digunakan untuk menggambarkan keadaan diri sendiri yang identik dengan kemiskinan, sekaligus merendahkan diri sendiri. Hal ini menunjukkan bahwa kearifan lokal Bali tercermin lewat penggunaan bahasa Bali secara utuh lirik-lirik lagu album Bali Kumara.

Berdasarkan hasil wawancara dengan Darmayuda di kediamannya pada tanggal 4 Oktober 2015, dijelaskan hal sebagai berikut: 
"Jaman semakin maju, teknologi semakin berkembang, dan informasi dalam bentuk budaya asing, bahasa asing, dan lain-lain akan membaur dalam kehidupan sehari-hari masyarakat Bali. Di sinilah kesempatan kita sebagai seniman untuk mengedukasi dan mengingatkan masyarakat untuk tetap melestarikan bahasa Bali sebagai salah satu kearifan lokal di tengah-tengah globalisasi".

Ditambahkannya lagi bahwa penggunaan basa singgih dalam lirik-lirik lagu album Bali Kumara merupakan salah satu siasat untuk melestarikan bahasa Bali itu sendiri. Hal ini menunjukkan bahwa komposer memang sengaja menggunakan basa singgih secara dominan pada lirik-lirik lagu album Bali Kumara. Tujuannya untuk melestarikan bahasa Bali yang merupakan salah satu kearifan lokal Bali dan untuk mengedukasi masyarakat akan pentingnya melestarikan bahasa Bali di tengahtengah derasnya gelombang globalisasi.

\section{SIMPULAN}

Kearifan lokal Bali dalam lagu-lagu album Bali Kumara terletak pada penggunaan tangga nada/titi laras pelog dan slendro, serta penggunaan bahasa Bali singgih dan sor. Tangga nada pelog dan slendro diimplementasikan pada melodimelodi utama, baik oleh alat musik keyboard, gamelan, maupun vokal. Pada beberapa lagu terdapat juga tangga nada lain, seperti diatonis dan kromatis, dimana tidak terlalu memudarkan warna pelog dan slendro. Jika dilihat dari sudut pandang sor singgih basa (tingkatan-tingkatan dalam bahasa Bali), sebagain besar lagu-lagu di album Bali Kumara menggunakan basa singgih, dan beberapa di antaranya menggunakan basa sor. Penggunaan basa singgih terdapat secara dominan pada lagu "Bali Asri Lestari”, "Bali Kasub", "Bali Jagat Seni”, "Bali Kumara”, "Dewi Saraswati", "Medokaran", "Ngrastitiang Jagat Bali", "Pewaris Jagat Bali", "Tangis Pertiwi”, "Taru Kelapane Suci”. Sedangkan penggunaan basa sor terdapat pada lagu "Bencana Ring Bali”, "I Lutung Jail”, dan "Muda Lara”.

Kearifan lokal Bali adalah salah satu hal yang dapat digunakan untuk membentuk suatu identitas kesenian. Lagu pop Bali sebagai salah satu kesenian profan yang tumbuh dan berkembang di Bali sudah seyogyanya mengandung unsurunsur kearifan lokal Bali. Beberapa siasat yang bisa dilakukan untuk memasukkan unsur kearifan lokal ke dalam lagu pop Bali ialah menggunaakan tangga nada pelog dan slendro pada melodi-melodi utama, serta menggunakan bahasa Bali yang baik seperti basa singgih. Kearifan lokal yang terkandung pada lagu-lagu album Bali 
Kumara dapat menjadi pijakan bagi para pelaku lagu pop Bali khususnya komposer dalam menciptakan karya-karya berikutnya, sehingga identitas lagu pop Bali tetap terjaga.

\section{REFERENSI}

Adnyana, Pande Putu P. 2014. Penguasaan Sor Singgih Bahasa Bali Dalam Keterampilan Berbicara Kelas IX SMP Negeri 3 Denpasar Tahun Pelajaran 2013/2014. Denpasar: Universitas Udayana.

Darmayuda, I Komang. 2007. "Lagu Pop Bali Periode 1990-2005 (Sebuah Kajian Budaya)", Tesis, Denpasar: Pascasarjana Universitas Udayana.

Dharna, I Gde. 2003. "Mencari "Bali” pada Lagu Pop Bali Masa Kini”, Bali Post, 30 Agustus, hal. 8.

Prabandani, H.W. 2018. "Pembangunan Hukum Berbasis Kearifan Lokal". www.birohukum.bappenas.go.id.

Sartini, Ni Wayan. 2009. Menggali Nilai-nilai Kearifan Lokal Budaya Jawa Lewat Ungkapam (Bebasan, Saloka, dan Paribasa). Palembang: Universitas Sumatera Selatan.

Sukerta, Pande Made. 1998. Ensiklopedia Karawitan Bali. Bandung: MSPI.

Tinggen, I Nengah. 1986. Sor Singgih Basa Bali. Singaraja: Rhika Dewata.

Mack, Dieter. 1995. Apresiasi Musik: Musik Populer. Yogyakarta: Yayasan Pustaka Nusatama.

Mack, Dieter. 2004. Musik Kontemporer dan Persoalan Interkultural. -: Arti.

Miles, Matthew B; Michael A. Huberman. 1992. Analisis Data Kualitatif. Jakarta: UII Press.

Narendra, Yuka Dian, Yunoke Rahma Andayani, and Ispawati Asri. 2009. "Copyright, Panopticon dan ISA: Hak Cipta dan Kesadaran Palsu dalam 
Industri Musik Indonesia", Marcommers Jurnal Marketing Communication \& Advertising, Vol. 1, No. 1, October, p. 92-107.

Storey, John. 2004. Teori Budaya dan Budaya Populer: Memetakan Lanskap Cultural Studies. Yogyakarta: CV. Qalam.

Storey, John. 2006. Cultural Studies dan Kajian Budaya Pop: Pengantar Komprehensif Teori dan Metode. Yogyakarta: Jalasutra. 